\title{
Effect of high temperature and recovery from stress on crop-weed interaction
}

\author{
Queli Ruchel $^{1}$ (D), Renan Ricardo Zandoná1,* (D), Diego Severo Fraga ${ }^{1}$ (D), Dirceu Agostinetto ${ }^{1}$ (D), \\ Ana Claudia Langaro ${ }^{1}$ (D) \\ 1. Universidade Federal de Pelotas - Faculdade de Agronomia - Departamento de Fitossanidade - Pelotas (RS), Brazil.
}

\begin{abstract}
Biotic and abiotic stresses, either individually or in combination, may affect soybean growth and development negatively, besides competitiveness with weeds. This study aimed at evaluating the effect of heat stress and plant recovery on crop-weed interaction by analyzing growth variables. Experiments were set up as replacement series of soybean with slender amaranth. Treatments followed a factorial scheme, which was composed of heat stress [high temperature $\left(38 / 22 \pm 2^{\circ} \mathrm{C}\right)$ against the control $\left(28 / 22 \pm 2{ }^{\circ} \mathrm{C}\right)$ ] and of proportions of soybean and slender amaranth, i.e., 100:0 (pure stand of soybean), 50:50 and 0:100 (pure stand of slender amaranth). After being submitted to high temperatures, plants were analyzed in terms of their recovery from heat stress. Variables under evaluation were height, leaf area and shoot dry weight. Results led to the conclusion that the weed shows more competitiveness than soybean, regardless of the heat stress. Interspecific competition for soybean and intraspecific competition for slender amaranth influence their height, leaf area and shoot dry weight negatively, while high temperature affects slender amaranth positively.
\end{abstract}

Key words: Glycine max, Amaranthus viridis, heat stress, competitiveness.
Received:

Apr. 5, 2020

Accepted:

Jul. 21, 2020

Section Editor:

Gabriel Constantino Blain

${ }^{*}$ Corresponding author: renan_zandona@hotmail.com

\section{INTRODUCTION}

Soybean (Glycine max L. Merr.) is an annual plant that belongs to the family Fabaceae, has the $\mathrm{C}_{3}$ photosynthetic pathway and is native from Asia (Ziska 2013). Brazil grew soybean crop over 36 million hectares in the 2019/2020 season, which meant about $60 \%$ of the country's total cultivated area with different crops, perennial and annual (CONAB 2020). Several factors, such as competition with weeds and environmental conditions that are unfavorable to crop development (for instance, high temperatures), may affect soybean productivity negatively.

Damage caused by weeds, which may lead up to $93 \%$ of productivity loss, is mainly the result of competition for resources that are available in the environment (carbon dioxide, light, water and nutrients) (Silva et al. 2009). Even though several weed species, which exhibit different competitive ability, are easily found in soybean, the species that are morphologically and/or physiologically close to it, such as slender amaranth (Amaranthus viridis L.), usually have similar requirements in terms of resources, a fact that makes competition more intense.

In order to determine competitive crop-weed interaction, several methods have been developed. They account for plant population, proportion of species and spatial arrangement, and usually evaluate characteristics of plant growth, such as height, leaf area and production of the shoot dry weight (Radosevich et al. 2007). Replacement series experiments include analyses of monocultures and mixtures of species under investigation; proportions of species vary while total plant population is 
kept constant in all treatments (Cousens 1991; Radosevich et al. 2007). Such models make it possible to study interspecific and intraspecific competition in the light of the fact that the yield of associations may be determined when compared with that of monocultures (Ulguim et al. 2016).

Heat stress is considered one of the main environmental factors that affect biological processes, limiting plant growth and productivity; it should be added that the effect of temperature on plant development and survival depends on stress intensity and length (Fahad et al. 2017). Studies have shown that global mean temperature may increase from 0.3 to $4.8^{\circ} \mathrm{C}$ up to the end of the century (Pachauri 2007). Thus, both increase in mean temperature and episodes of extreme temperatures for short time periods may generate negative and irreparable impacts on crop growth and development (Fahad et al. 2017).

Biochemical, physiological and morphological changes are common under high temperature stress, can cause serious damage to proteins, damage membranes, influence the relationship of water and nutrients, interfere with photosynthesis and balance of assimilates, promoting oxidative damage, affecting growth and development of plants, resulting in reduction in yield (Fahad et al. 2017).

Responses to biotic and abiotic stresses, either individually or in combination, may vary among crops and weeds, mainly among plants with different photosynthetic pathways $\left(\mathrm{C}_{3}\right.$ or $\left.\mathrm{C}_{4}\right)$. Therefore, studies that evaluate competitive interactions between $\mathrm{C}_{3}$ and $\mathrm{C}_{4}$ plants, mainly crop-weed interactions in agricultural systems, get more important when the setting is undergoing environmental changes. Little is known about the effect of climate alterations on soybean production, since combination of stresses affects not only the crop itself, but also its interaction with the weed. Therefore, this study aimed at evaluating the effect of heat stress and plant recovery on crop-weed interaction by analyzing growth variables.

\section{METHODS}

The experiment was carried out in a greenhouse and set up as replacement series in the 2015/2016 growing season, as a completely randomized design, with four replicates. The soybean cultivar NA 5909 RG and slender amaranth seeds collected in a nonagricultural area were used for conducting the study.

Experimental units were composed of 4-L vases, $22 \mathrm{~cm}$ in diameters. Sowing was carried out on polyethylene trays. When plants had their first true expanded leaves, 10 and 15 days after soybean and slender amaranth emergence, respectively, they were transplanted to vases full of sieved soil, classified into Red-Yellow Argisol, with loamy-sandy texture. Soil fertility was corrected by applying $220 \mathrm{~kg} \cdot \mathrm{ha}^{-1}$ fertilizer (05-20-20), in agreement with laboratory analyses and technical recommendations issued for soybean crops.

Treatments were arranged in a factorial scheme $(2 \times 3)$. Factor A consisted of the control temperature $28 / 22 \pm 2{ }^{\circ} \mathrm{C}$ and the high temperature $38 / 22 \pm 2{ }^{\circ} \mathrm{C}$, where the thermal amplitudes day/night were $10 / 14 \mathrm{~h}$. Factor B comprised proportions of soybean and slender amaranth, i.e., 100:0 (pure stand of soybean), 50:50 and 0:100 (pure stand of slender amaranth), which are equivalent to 10:0, 5:5 and 0:10 plants $\cdot v^{-1} e^{-1}$, respectively.

Plant populations were determined by a previous experiment which had populations of 8 and 12 plants per experimental unit, equivalent to 193 and 289 plants $\mathrm{m}^{-2}$ for soybean and slender amaranth, respectively, in agreement with the "law of final constant yield" (Radosevich et al. 2007) (data not shown). Population per experimental unit was found by calculating the arithmetic mean of populations, which resulted in 10 plants $\cdot v^{-1} \mathrm{e}^{-1}$, equivalent to 241 plants $\cdot \mathrm{m}^{-2}$, when soybean and slender amaranth grew together.

Plants were kept in the greenhouse up to 20 days after transplant (DAT) in similar conditions of humidity and temperature. Afterwards, they were transferred to small greenhouses where temperature was controlled and thermal treatments were applied. The analysis of variables under stress (control and high temperatures) was carried out 40 DAT (20 days after treatment), with four replicates. Height (HEI), leaf area (LA) and shoot dry weight (SDW) of soybean and the competitor (soybean in stage $\mathrm{V}_{4}-\mathrm{V}_{6}$; slender amaranth with 8-9 leaves) were evaluated in a stressful situation (SS). Four experimental units submitted to high temperature were set back to the control conditions 40 DAT so as to evaluate plant recovery (recovery from high temperature: R-HT). HEI, LA and SDW (soybean in stage $\mathrm{V}_{8}$; slender amaranth with 10-12 leaves) were analyzed 10 days after R-HT. 
Height of all plants was measured in every replicate by a millimeter ruler, from the level of the soil to the apex of the leaf, with its distended limbo. Leaf area was determined by a leaf area meter, model LI $3200 \mathrm{C}$; values were obtained as $\mathrm{cm}^{2}$ and converted into $\mathrm{cm}^{2}$. plant ${ }^{-1}$. Shoot dry weight was quantified after drying in an oven with forced air circulation at $6{ }^{\circ} \mathrm{C}$ for $72 \mathrm{~h}$ and expressed as $\mathrm{g} \cdot$ plant $^{-1}$.

The method of graphical analysis of relative productivity (RP) (Radosevich et al. 2007; Cousens 1991) was used for analyzing data on HEI, LA and SDW, as described by Ruchel et al. (2019) and Silva et al. (2017). The criterion to consider the existence of differences in competitive ability, regarding indexes of relative competitiveness (RC), coefficient of relative clustering (K) and coefficient of competitiveness (C), calculated in the 50:50 proportion, was that the T-test should show differences in at least two of them (Bianchi et al. 2006). Relative competitiveness represents comparative growth of the crop (soybean) in relation to it competitor (slender amaranth); $\mathrm{K}$ indicates relative dominance of a species over others; and $\mathrm{C}$ shows which species is more competitive (Cousens 1991).

Data on HEI, LA and SDW, expressed as mean values per plant, were submitted to the analysis of variance ( $\mathrm{p} \leq 0.05)$. When statistical significance was found, heat stress and proportions were compared by the T-test $(\mathrm{p} \leq 0.05)$ in every competitive species.

\section{RESULTS AND DISCUSSION}

Concerning HEI of soybean plants coexisting with slender amaranth (Amaranthus viridis L.) in an SS, deviations in the RP straight line were found to be represented by a concave line for the soybean crop and a convex line for slender amaranth in the control treatment (Fig. 1a) and a line close to the hypothetical straight line at high temperature for both plants
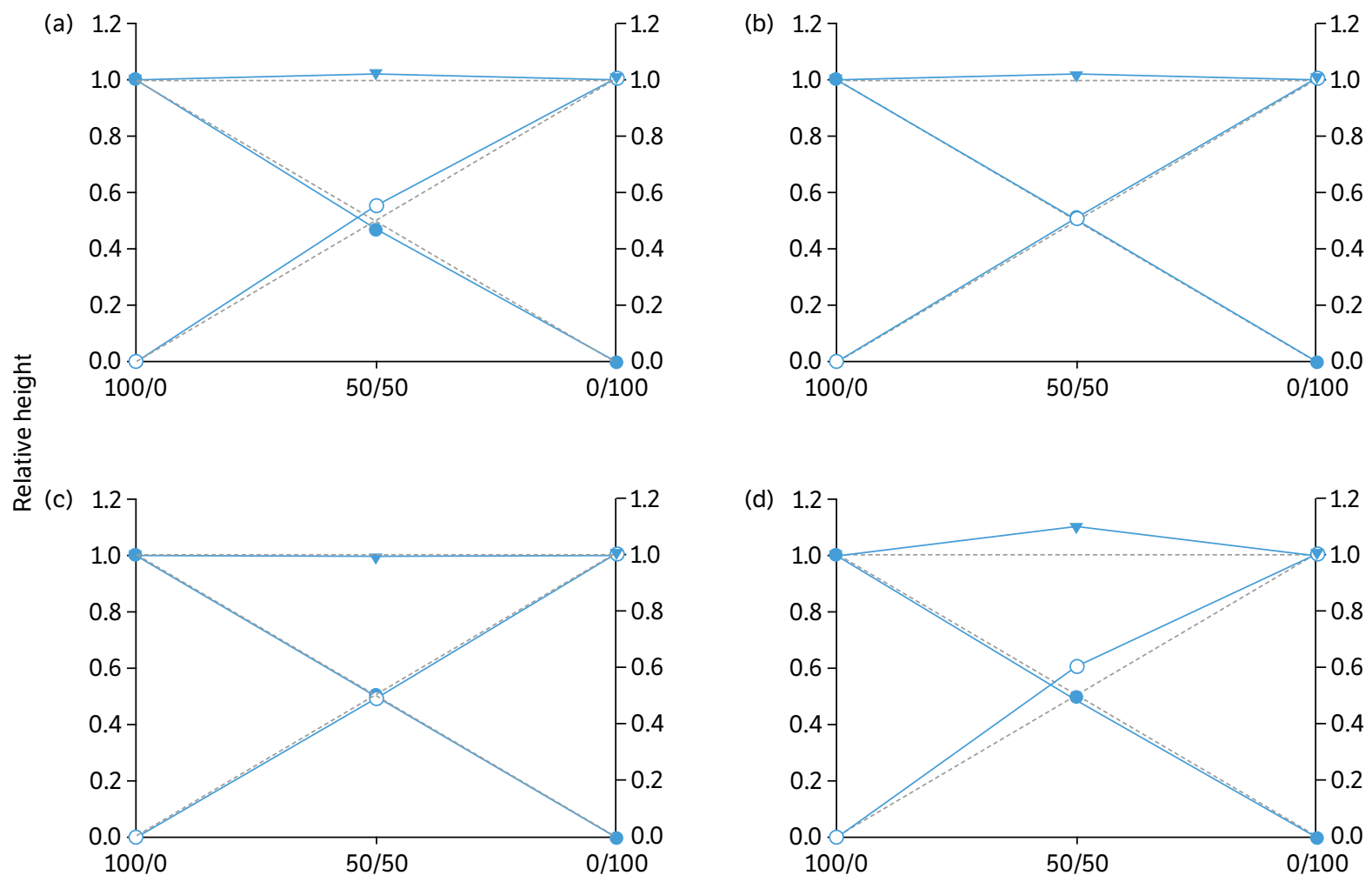

Proportions of soybean and slender amaranth (\%)

Figure 1. Relative productivity (RP) and total relative productivity (TRP) of soybean and slender amaranth height (HEI) as the result of proportions between both species in the population in a stress situation (SS) [control (a) and high temperature (b)] and plant recovery from stress [control (c) and R-HT (d)]. (๑) RP of soybean; ( $($ ) RP of slender amaranth; and ( $v$ ) TRP. Dashed lines refer to hypothetical relative productivities, when species do not interfere with each other. 
(Fig. 1b). In this situation, at control temperature, soybean was less competitive than the weed, while, at high temperature, both plants gave similar responses.

Similar result was found in barnyardgrass (Echinochloa crus-galli L., $\mathrm{C}_{4}$ pathway), which exhibited higher HEI than the soybean 'BMX Apolo RR', a short-stature cultivar, whose cycle is very precocious; this fact showed its high competitiveness, by comparison with the crop (Bastiani et al. 2016). A study of soybean competing with goosegrass (Eleusine indica L.) $\left(\mathrm{C}_{4}\right)$ showed values that were close to the hypothetical ones; thus, plants did not interfere with each other in terms of HEI (Wandscheer et al. 2013 a).

Concerning recovery from stress, deviations found in the RP straight line in the control were represented by a line close to the hypothetical straight line of soybean and slender amaranth HEI (Fig. 1c), while in R-HT, deviations in the RP straight line were represented by a line close to the hypothetical one for soybean and a convex line for slender amaranth (Fig. 1d). Studies of competitive ability of corn $\left(\mathrm{C}_{4}\right)$ coexisting with goosegrass $\left(\mathrm{C}_{4}\right)$ showed that, in the case of HEI, the weed had better competitive results (Wandscheer et al. 2013 b). Variation in height in situations in which there is competition may be associated with the strategy plants use to capture the maximum amount of sunlight, thus, causing plant stultification and, consequently, low investment in growth.

The analysis of combinations of plants in a SS in terms of LA showed that deviations found in the RP straight line were represented by a concave line for soybean in both control and high temperature treatments and by convex lines for slender amaranth in both treatments (Figs. 2a-b). Regarding recovery from stress, results of soybean and slender amaranth corroborate the previously mentioned results found by both treatments (Figs. 2c-d).

Concerning LA, in general, regardless of the heat stress, the soybean crop $\left(\mathrm{C}_{3}\right)$ had lower competitive ability than the $\mathrm{C}_{4}$ weed (Figs. 2a-d). However, the competitive response between $\mathrm{C}_{3}$ plants can demonstrate positive results for the crop, harming the weed. For example, bean cultivars exhibited low relative loss, decreased morphological variables of beggarticks (Bidens pilosa L.) and showed higher competitive ability than the weed (Galon et al. 2017).
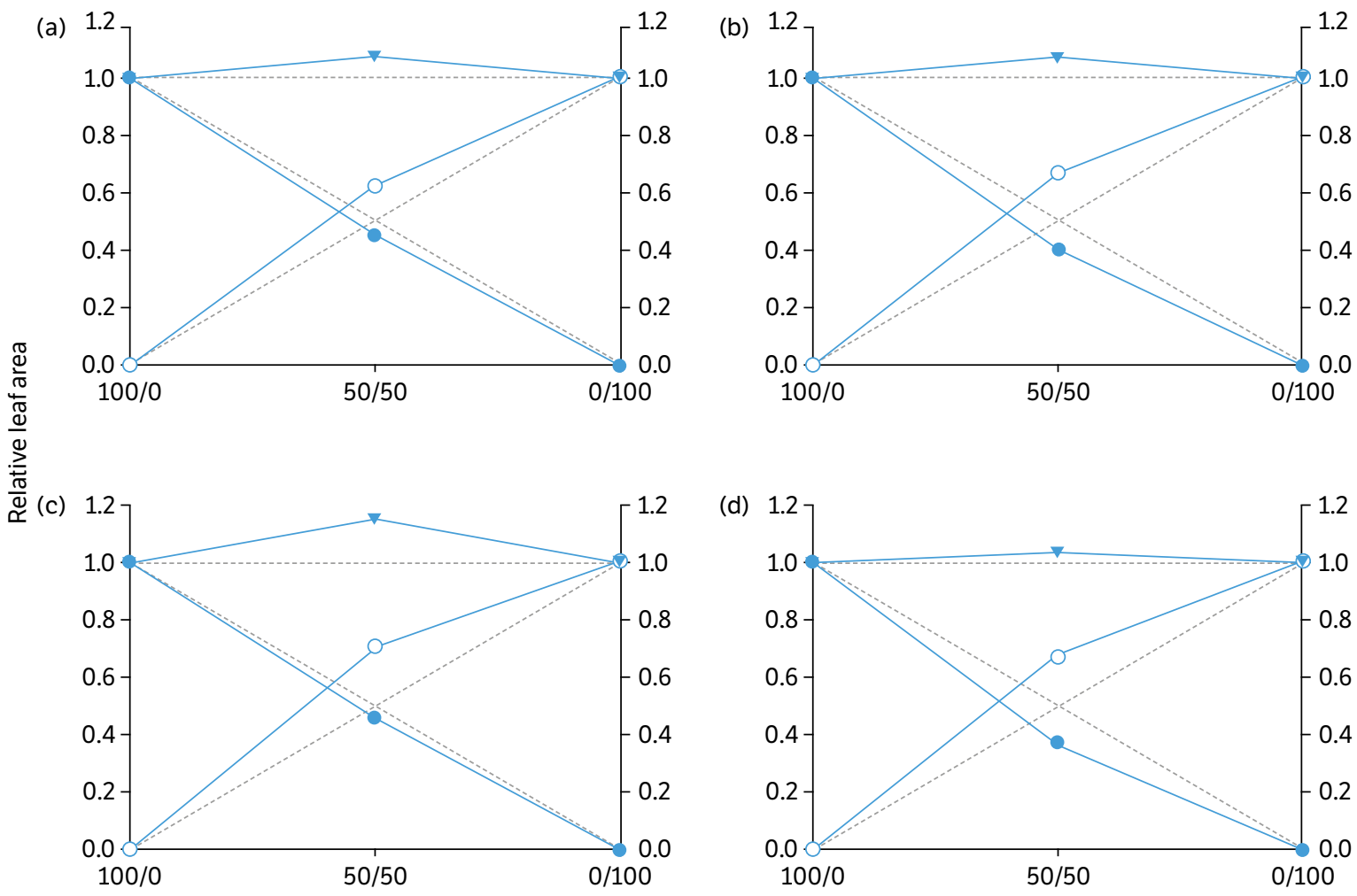

Proportions of soybean and slender amaranth (\%)

Figure 2. Relative productivity (RP) and total relative productivity (TRP) of soybean and slender amaranth leaf area (LA) as the result of proportions between both species in the population in a stress situation (SS) [control (a) and high temperature (b)] and plant recovery from stress [control (c) and R-HT (d)]. (๑) RP of soybean; ( $)$ RP of slender amaranth; and ( $\vee$ ) TRP. Dashed lines refer to hypothetical relative productivities, when species do not interfere with each other. 
In terms of SDW of soybean plants in a SS, deviations found in the RP straight line were represented by a convex line for the soybean crop in the control treatment and by a concave line at high temperature (Figs. 3a-b). In the case of slender amaranth, deviations found in the RP straight line were represented by convex lines in both treatments (Figs. 3a-b). At control temperature, soybean was not damaged by competition; there was decrease in SDW at high temperature, while the weed coexisting with soybean had its RP increased, regardless of the heat stress under study (Figs. 3a-d).

The analysis of soybean SDW in recovery from stress showed that deviations found in the RP straight line were represented by a line close to the hypothetical one in the control and R-HT treatments (Figs. 3c-d). In the case of slender amaranth, deviations found in the RP line were represented by a convex line in both treatments, a fact that showed there was no damage resulting from competition.

Studies have shown that even low weed populations may damage crops on the field. Examples are barley competing with ryegrass (Lolium multiflorum L.) (Galon et al. 2011) and soybean competing with forage radish (Raphanus sativus L.) (Bianchi et al. 2006). Concave lines were found in all LA and SDW simulations of bean cultivars and beggarticks coexisting with each other; it shows that they competed for the same resources in the environment (Galon et al. 2017).

In a SS, relative differences between observed lines (differences in relative productivity - DRP) and expected ones were significant in the cases of LA and SDW of the crop and the weed in both treatments (control and high temperature), while soybean and slender amaranth HEI only differed in the control treatment (Table 1). Soybean competing with horseweed biotypes (Conyza bonariensis L., $\mathrm{C}_{3}$ ) exhibited significant DRP in HEI, LA and SDW, i.e., values were lower than the expected ones (Silva et al. 2014), a fact that corroborates data found by the study reported in this paper.

Concerning TRP in a SS, differences were found in LA in both treatments under study and in SDW in the control treatment; since values were above one, species did not compete for environmental resources (Table 1). Contrasting results
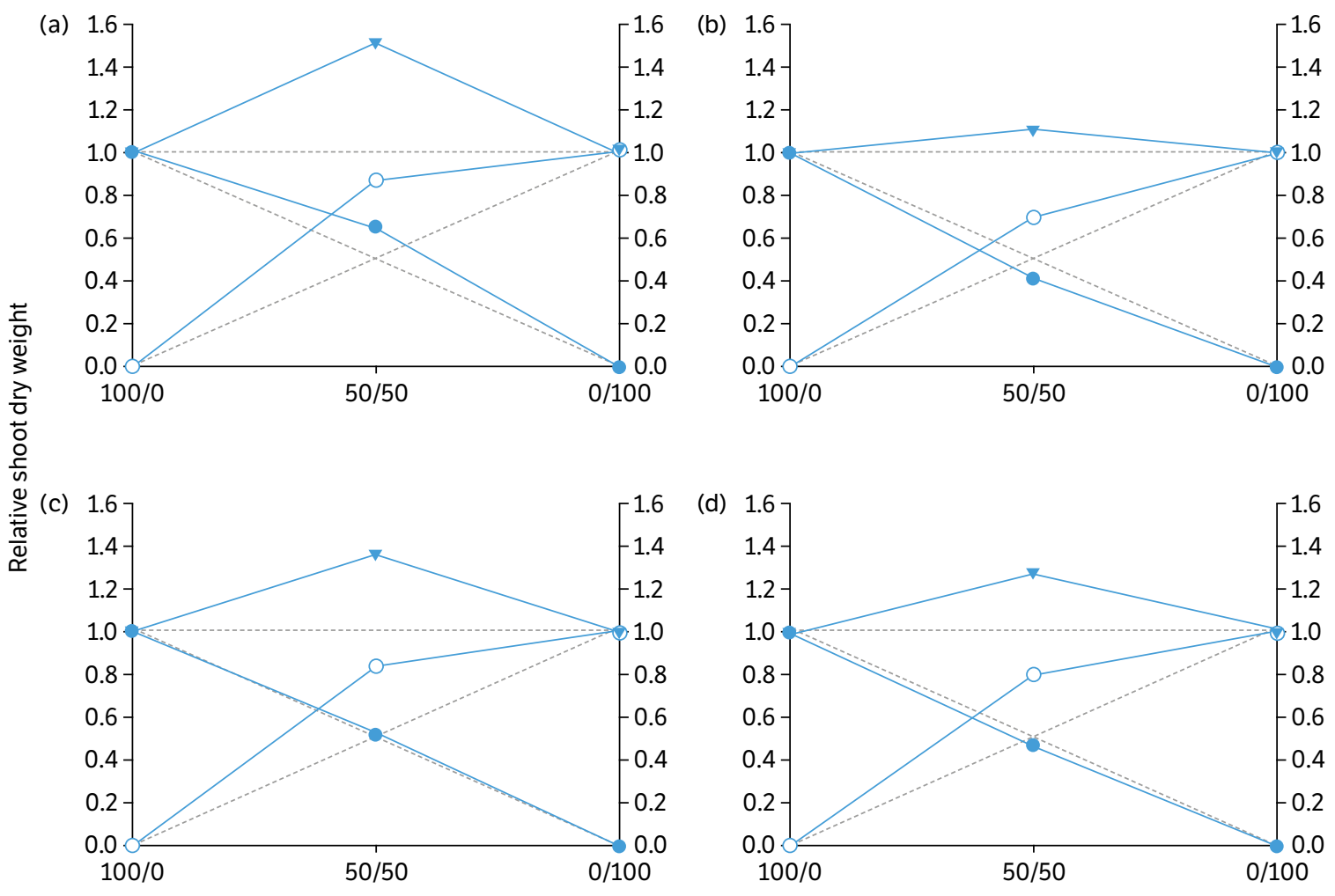

Proportions of soybean and slender amaranth (\%)

Figure 3. Relative productivity (RP) and total relative productivity (TRP) of soybean and slender amaranth shoot dry weight (SDW) as the result of proportions between both species in the population in a stress situation (SS) [control (a) and high temperature (b)] and plant recovery from stress [control (c) and R-HT (d)]. (๑) RP of soybean; (○) RP of slender amaranth; and ( $\vee$ ) TRP. Dashed lines refer to hypothetical relative productivities, when species do not interfere with each other. 
Table 1. Differences in relative productivity (DRP) for height, leaf area and total relative productivity (TRP), in the proportion of 50:50 (\%) of soybean plants associated with slender amaranth ones, in a stressful situation (control and high temperature) and recovery from stress (control and R-HT).

\begin{tabular}{|c|c|c|c|c|}
\hline \multirow{2}{*}{ Variable } & \multicolumn{2}{|c|}{ Stressful situation } & \multicolumn{2}{|c|}{ Recovery from stress } \\
\hline & Control & High temperature & Control & R-HT \\
\hline & \multicolumn{4}{|c|}{ Height (HEI) } \\
\hline $\mathrm{DRP}_{\text {soybean }}$ & $-0.03( \pm 0.00)^{\star}$ & $0.01( \pm 0.02)^{\mathrm{ns}}$ & $0.00( \pm 0.01)^{\mathrm{ns}}$ & $-0.00( \pm 0.02)^{\mathrm{ns}}$ \\
\hline $\mathrm{DRP}_{\text {amaranth }}$ & $0.05( \pm 0.01)^{\star}$ & $0.00( \pm 0.01)^{\mathrm{ns}}$ & $-0.01( \pm 0.01)^{\mathrm{ns}}$ & $0.10( \pm 0.02)^{\star}$ \\
\hline \multirow[t]{2}{*}{ TRP } & $1.02( \pm 0.01)^{\mathrm{ns}}$ & $1.01( \pm 0.01)^{\mathrm{ns}}$ & $0.99( \pm 0.01)^{\mathrm{ns}}$ & $1.10( \pm 0.03)^{\mathrm{ns}}$ \\
\hline & \multicolumn{4}{|c|}{ Leaf area (LA) } \\
\hline $\mathrm{DRP}_{\text {soybean }}$ & $-0.05( \pm 0.01)^{\star}$ & $-0.10( \pm 0.01)^{\star}$ & $-0.04( \pm 0.01)^{\star}$ & $-0.13( \pm 0.01)^{*}$ \\
\hline $\mathrm{DRP}_{\text {amaranth }}$ & $0.12( \pm 0.01)^{\star}$ & $0.17( \pm 0.01)^{\star}$ & $0.21( \pm 0.03)^{\star}$ & $0.18( \pm 0.02)^{\star}$ \\
\hline \multirow[t]{2}{*}{ TRP } & $1.08( \pm 0.01)^{\star}$ & $1.07( \pm 0.02)^{\star}$ & $1.16( \pm 0.03)^{\star}$ & $1.05( \pm 0.02)^{\mathrm{ns}}$ \\
\hline & \multicolumn{4}{|c|}{ Shoot dry weight (SDW) } \\
\hline $\mathrm{DRP}_{\text {soybean }}$ & $0.14( \pm 0.01)^{\star}$ & $-0.09( \pm 0.01)^{\star}$ & $0.01( \pm 0.01)^{\mathrm{ns}}$ & $-0.03( \pm 0.01)^{\mathrm{ns}}$ \\
\hline $\mathrm{DRP}_{\text {amaranth }}$ & $0.37( \pm 0.01)^{\star}$ & $0.20( \pm 0.04)^{\star}$ & $0.34( \pm 0.02)^{\star}$ & $0.31( \pm 0.02)^{\star}$ \\
\hline TRP & $1.51( \pm 0.02)^{\star}$ & $1.11( \pm 0.04)^{n s}$ & $1.35( \pm 0.02)^{\star}$ & $1.28( \pm 0.02)^{\star}$ \\
\hline
\end{tabular}

ns Not significant; and * significant in relation to the hypothetical straight line by the T-test $(p \leq 0.05)$. Values between parentheses represent the standard error of the mean.

were found by the analysis of competitive ability of soybean coexisting with beggarticks and wild poinsettia (Euphorbia heterophylla L.); decrease in growth may have been the result of their coexistence (Forte et al. 2017).

Regarding recovery from stress, significant DRP were only found in soybean LA, in both treatments (control and R-HT) (Table 1). In the case of slender amaranth competing with soybean, differences in LA and SDW were found in both treatments, while differences in HEI were only found in R-HT. Thus, it may be inferred that, in general, weeds benefited but the crop was damaged. Competition between bean and beggarticks for the same environmental resources led to negative interference in plant growth, regardless of the plant proportion (Galon et al. 2017).

Concerning TRP in recovery from stress, significant differences were found in LA in the control treatment and in SDW in both treatments under study (Table 1). Values above one were found in LA and SDW in recovery from stress; weeds contributed more in the mixture. The sum of soybean SDW and horseweed SDW was higher than expected, a fact that shows that mixed species produce more than monocultures (Silva et al. 2014).

Considering that soybean is more competitive than slender amaranth when $\mathrm{RC}>1, \mathrm{~K}_{\text {soybean }}>\mathrm{K}_{\text {amaranth }}$ and $\mathrm{C}>0$ (Hoffman and Buhler 2002) and adopting such criterion to prove its competitive superiority and the occurrence of differences in at least two of these indexes (Bianchi et al. 2006), in all variables under study (HEI, LA and SDW - Table 2), the weed with a $\mathrm{C}_{4}$ cycle was found to exhibit more competitiveness than the soybean crop $\left(\mathrm{C}_{3}\right)$, regardless of the temperature (both in a stressful situation and recovery from stress).

Effects of weed species result mainly from the combination of their total population, rather than from their individual competition. It should also be highlighted that, in the competition for resources, plants that either establish themselves first or have characteristics, such as good height, fast growth, large leaf area and high dry mass, that enable high competitive ability, benefit from them and, consequently, lower amounts of resources keep available in the environment, a fact that leads to increase in damage to the competitor or crop (Agostinetto et al. 2013).

Some studies have reported that weeds exhibit more competitive ability than crops, such as competitions between alexandergrass [Brachiaria plantaginea (Link) Hitchc.] and Benghal dayflower (Commelina benghalensis L.) competing with soybean (Dias et al. 2010) and ryegrass competing with barley (Galon et al. 2011). On the other hand, crabgrass (Digitaria spp.) $\left(\mathrm{C}_{4}\right)$, beggarticks $\left(\mathrm{C}_{3}\right)$, wild poinsettia $\left(\mathrm{C}_{3}\right)$ and goosegrass $\left(\mathrm{C}_{4}\right)$ exhibited decrease in HEI, LA and SDW when competing with soybean (Agostinetto et al. 2013; Forte et al. 2017; Franco et al. 2017). 
Table 2. Competitiveness indexes between soybean and slender amaranth evaluated in a stressful situation (control and high temperature) and recovery from stress (control and R-HT), expressed as relative competitiveness (RC), coefficient of relative clustering (K) and coefficient of competitiveness $(C)$.

\begin{tabular}{|c|c|c|c|c|}
\hline \multirow{2}{*}{ Indexes } & \multicolumn{2}{|c|}{ Stressful situation } & \multicolumn{2}{|c|}{ Recovery from stress } \\
\hline & Control & High temperature & Control & R-HT \\
\hline & \multicolumn{4}{|c|}{ Height (HEI) } \\
\hline $\mathrm{RC}$ & $0.88( \pm 0.01)^{\star}$ & $1.01( \pm 0.06)^{\mathrm{ns}}$ & $1.02( \pm 0.04)^{\mathrm{ns}}$ & $0.83( \pm 0.01)^{\star}$ \\
\hline $\mathrm{K}_{\text {soybean }}$ & $0.87( \pm 0.01)^{\star}$ & $1.03( \pm 0.07)^{\mathrm{ns}}$ & $1.00( \pm 0.04)^{\mathrm{ns}}$ & $1.00( \pm 0.06)^{\star}$ \\
\hline $\mathrm{K}_{\text {amaranth }}$ & $1.14( \pm 0.04)$ & $1.02( \pm 0.06)$ & $0.97( \pm 0.05)$ & $1.51( \pm 0.10)$ \\
\hline \multirow[t]{2}{*}{ C } & $-0.06( \pm 0.01)^{*}$ & $0.00( \pm 0.03)^{\mathrm{ns}}$ & $0.01( \pm 0.02)^{\mathrm{ns}}$ & $-0.10( \pm 0.00)^{\star}$ \\
\hline & \multicolumn{4}{|c|}{ Leaf area (LA) } \\
\hline $\mathrm{RC}$ & $0.73( \pm 0.02)^{\star}$ & $0.60( \pm 0.02)^{\star}$ & $0.65( \pm 0.04)^{*}$ & $0.55( \pm 0.02)^{\star}$ \\
\hline $\mathrm{K}_{\text {soybean }}$ & $0.83( \pm 0.02)^{\star}$ & $0.68( \pm 0.03)^{\star}$ & $0.85( \pm 0.04)^{\star}$ & $0.59( \pm 0.03)^{\star}$ \\
\hline $\mathrm{K}_{\text {amaranth }}$ & $1.67( \pm 0.09)$ & $2.03( \pm 0.13)$ & $2.53( \pm 0.37)$ & $2.15( \pm 0.16)$ \\
\hline \multirow[t]{2}{*}{ C } & $-0.17( \pm 0.01)^{\star}$ & $-0.27( \pm 0.02)^{\star}$ & $-0.25( \pm 0.04)^{\star}$ & $-0.31( \pm 0.02)^{\star}$ \\
\hline & \multicolumn{4}{|c|}{ Shoot dry weight (SDW) } \\
\hline $\mathrm{RC}$ & $0.74( \pm 0.01)^{\star}$ & $0.59( \pm 0.05)^{\star}$ & $0.61( \pm 0.02)^{\star}$ & $0.59( \pm 0.01)^{\star}$ \\
\hline $\mathrm{K}_{\text {soybean }}$ & $1.82( \pm 0.07)^{\star}$ & $0.69( \pm 0.03)^{\star}$ & $1.06( \pm 0.04)^{\star}$ & $0.90( \pm 0.04)^{\star}$ \\
\hline $\mathrm{K}_{\mathrm{amaranth}}$ & $6.79( \pm 0.50)$ & $2.52( \pm 0.43)$ & $5.42( \pm 0.67)$ & $4.33( \pm 0.56)$ \\
\hline C & $-0.23( \pm 0.00)^{\star}$ & $-0.29( \pm 0.05)^{\star}$ & $-0.33( \pm 0.02)^{\star}$ & $-0.31( \pm 0.02)^{\star}$ \\
\hline
\end{tabular}

ns Not significant; and * significant by the T-test $(p \leq 0.05)$. Values between parentheses represent standard errors of the means.

In the case of soybean in a stressful situation, there was interaction between heat stress and plant proportion for SDW and simple effect of plant proportion on LA; there was no statistical significance in HEI (Table 3). Simple effect of both factors for slender amaranth SDW was found, while only plant proportion affected its HEI and LA.

Regarding recovery from stress, there was interaction between factors analyzed for soybean LA, simple effect of heat stress on HEI, but there was no statistical significance in SDW (Table 3). Interaction was found between factors under study for slender amaranth HEI and simple effect of both factors on its LA and SDW.

In a stressful situation, soybean exhibited decrease in LA when it coexisted with slender amaranth (50:50) in both treatments and decrease in SDW at high temperature, a fact that showed that interspecific competition was harmful to the crop, regardless of temperature (Table 3). In the case of the weed in a SS, there was decrease in HEI, LA and SDW when it was a monoculture at both temperatures. In addition, at high temperature there was increase in SDW in a SS.

There was decrease in LA of soybean coexisting with slender amaranth during recovery from stress in both treatments; values decreased even more when the crop underwent R-HT (Table 3). Slender amaranth exhibited the highest value of HEI in the R-HT treatment and in the mixture with soybean. Low values of weed LA and SDW, as a monoculture, were found, by comparison with the mixture, while values of variables increased in the R-HT treatment.

Results show that, in general, interspecific competition was predominant in soybean crop, since it influenced morphological variables negatively, regardless of the heat stress under investigation (either a stressful situation or recovery from stress). Intraspecific competition led to high damage to the weed, due to the phenotypical proximity of plants, and consequent competition for the same environmental niche, regardless of temperature. In general, treatments at high temperatures and $\mathrm{R}$-HT led to a positive effect on morphological variables of the $\mathrm{C}_{4}$ weed. Studies of populations of rice and soybean with crabgrass (Agostinetto et al. 2013) and bean and beggarticks (Galon et al. 2017) showed that interspecific competition is less harmful to both species involved in the process than intraspecific competition.

High temperatures have adverse effect on soybean growth rate, damage blooming and decrease capacity of pod retention (Allen Junior et al. 2018), which is worsen by water deficit. Similarly, there are reports of decrease in HEI, SDW and number of trefoils of soybean competing with weeds (Carvalho et al. 2010). 
Table 3. Response of soybean crop to slender amaranth interference, evaluated in a stressful situation (control and high temperature) and recovery from stress (control and $\mathrm{R}-\mathrm{HT}$ ).

\begin{tabular}{|c|c|c|c|c|c|c|}
\hline \multirow{2}{*}{$\begin{array}{l}\text { Proportion } \\
\text { Soybean/ } \\
\text { amaranth }\end{array}$} & \multicolumn{3}{|c|}{ Stressful situation } & \multicolumn{3}{|c|}{ Recovery from stress } \\
\hline & Control & $\begin{array}{c}\text { High } \\
\text { temperature }\end{array}$ & Average & Control & R-HT & Average \\
\hline & \multicolumn{6}{|c|}{ Height (HEI - cm) } \\
\hline $100 \%$ soybean & 60.63 NS & 55.23 & & 63.74 & 59.82 & \\
\hline $50 \%$ soybean & 56.99 & 56.00 & & 63.77 & 58.70 & \\
\hline Average & & & & $63.76 a$ & $59.26 b$ & \\
\hline C.V. (\%) & & 5.50 & & & 4.72 & \\
\hline $100 \%$ amaranth & 42.21 & 45.74 & $43.98 \mathrm{~B}$ & $50.37 \mathrm{Aa}$ & $46.54 \mathrm{Ba}$ & \\
\hline $50 \%$ amaranth & 46.82 & 46.14 & $46.48 \mathrm{~A}$ & $49.50 \mathrm{Ab}$ & $55.85 \mathrm{Aa}$ & \\
\hline \multicolumn{7}{|l|}{ Average } \\
\hline \multirow[t]{2}{*}{ C.V. (\%) } & & 4.64 & & & 6.02 & \\
\hline & \multicolumn{6}{|c|}{ Leaf area $\left(\mathrm{LA}-\mathrm{cm}^{2} \cdot\right.$ plant $\left.^{-1}\right)$} \\
\hline $100 \%$ soybean & 271.00 & 289.70 & $280.35 \mathrm{~A}$ & $281.86 \mathrm{Aa}$ & $282.63 \mathrm{Aa}$ & \\
\hline $50 \%$ soybean & 245.33 & 233.70 & $239.51 \mathrm{~B}$ & $258.17 \mathrm{Ba}$ & $208.97 \mathrm{Bb}$ & \\
\hline \multicolumn{7}{|l|}{ Average } \\
\hline C.V. (\%) & & 4.52 & & & 4.10 & \\
\hline $100 \%$ amaranth & 200.80 & 190.00 & $195.40 \mathrm{~B}$ & 198.54 & 248.70 & $223.62 \mathrm{~B}$ \\
\hline $50 \%$ amaranth & 250.90 & 254.00 & $252.45 \mathrm{~A}$ & 280.67 & 338.05 & $309.36 \mathrm{~A}$ \\
\hline Average & & & & $239.60 \mathrm{~b}$ & 293.38 a & \\
\hline \multirow[t]{2}{*}{ C.V. (\%) } & & 4.60 & & & 6.08 & \\
\hline & \multicolumn{6}{|c|}{ Shoot dry weight (SDW - g.plant $\left.{ }^{-1}\right)$} \\
\hline $100 \%$ soybean & $1.83 \mathrm{Bb}$ & $2.42 \mathrm{Aa}$ & & $2.38^{\mathrm{NS}}$ & 2.48 & \\
\hline $50 \%$ soybean & $2.36 \mathrm{Aa}$ & $1.97 \mathrm{Bb}$ & & 2.45 & 2.34 & \\
\hline \multicolumn{7}{|l|}{ Average } \\
\hline C.V. $(\%)$ & & 3.99 & & & 4.62 & \\
\hline $100 \%$ amaranth & 1.82 & 3.11 & $2.47 \mathrm{~B}$ & 2.17 & 2.90 & $2.53 \mathrm{~B}$ \\
\hline $50 \%$ amaranth & 3.16 & 4.36 & $3.76 \mathrm{~A}$ & 3.65 & 4.69 & $4.17 \mathrm{~A}$ \\
\hline Average & $2.49 \mathrm{~b}$ & $3.73 \mathrm{a}$ & & $2.91 \mathrm{~b}$ & $3.80 \mathrm{a}$ & \\
\hline C.V. (\%) & & 13.01 & & & 10.39 & \\
\hline
\end{tabular}

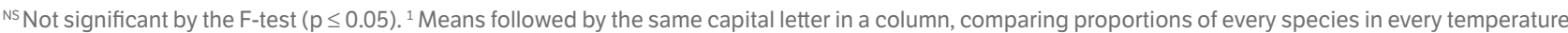
treatment, do not differ significantly by the T-test $(\mathrm{p} \leq 0.05) .{ }^{2}$ Means followed by the same small letter on a line, comparing every proportion in different temperature treatments, do not differ significantly by the T-test $(p \leq 0.05)$.

Therefore, in the light of these data and considering that there are few studies of the effect of climate changes on cropweed interaction, further studies of the evaluation of competitive interaction among plants with different photosynthetic pathways $\left(\mathrm{C}_{3}\right.$ and/or $\left.\mathrm{C}_{4}\right)$ under distinct abiotic stress may help to select plants with more competitive ability and to predict structure and composition of plant communities, besides changes in species geographical distribution.

\section{CONCLUSION}

The weed slender amaranth $\left(\mathrm{C}_{4}\right)$ exhibits more competitiveness than soybean $\left(\mathrm{C}_{3}\right)$, regardless of the heat stress under investigation (stressful situation and/or recovery from stress). Interspecific competition influences height, leaf area and shoot dry weight of soybean negatively, while intraspecific competition does the same with slender amaranth. High temperature affects slender amaranth positively. 


\section{ACKNOWLEDGMENTS}

The authors thank to CNPq for the Research Fellowship of Dr. Dirceu Agostinetto. Process n. 308363/2018-3, to the Federal University of Pelotas and to the Crop Protection Graduate Program.

\section{FUNDERS}

Coordenação de Aperfeiçoamento de Pessoal de Nível Superior

Finance Code 001

\section{AUTHOR'S CONTRIBUTION}

Conceptualization: Ruchel Q. and Agostinetto D.; Methodology: Ruchel: Q.: Zandoná R. R.: Fraga D.: Langaro: A. C.; Investigation: Ruchel: Q.: Zandoná R. R.: Fraga D. Langaro: A. C.; Writing - Original Draft: Ruchel Q. and Agostinetto D.; Writing - Review and Editing: Ruchel: Q.: Zandoná R. R.: Fraga D.: Langaro: A. C.; Funding Acquisition: Agostinetto D.; Resources: Ruchel Q. and Agostinetto D.; Supervision: Agostinetto D.

\section{REFERENCES}

Agostinetto, D., Fontana, L. C., Vargas, L., Markus, C. and Oliveira, E. (2013). Habilidade competitiva relativa de milhã em convivência com arroz irrigado e soja. Pesquisa Agropecuária Brasileira, 48, 1315-1322. https://doi.org/10.1590/S0100-204X2013001000002

Allen Junior, L. H., Zhanga, L., Booteb, K. J. and Hauser, B. A. (2018). Elevated temperature intensity, timing and duration of exposure affect soybean internode elongation, mainstem node number and pod number per plant. The Crop Journal, 6, 148-161. https://doi. org/10.1016/j.cj.2017.10.005

Bastiani, M. O., Lamego, F. P., Agostinetto, D., Langaro, A. C. and Silva, D. C. (2016) Relative competitiveness of soybean cultivars with barnyardgrass. Bragantia, 75, 435-445. https://doi.org/10.1590/1678-4499.412

Bianchi, M. A., Fleck, N. G. and Lamego, F. P. (2006). Proporção entre plantas de soja e plantas competidoras e as relações de interferência mútua. Ciência Rural, 36, 1380-1387. https://doi.org/10.1590/S0103-84782006000500006

Carvalho, L. B., Bianco, S. and Guzzo, C. D. (2010). Interferência de Euphorbia heterophylla no crescimento e acúmulo de macronutrientes da soja. Planta Daninha, 28, 33-39. https://doi.org/10.1590/S0100-83582010000100004

[CONAB] Companhia Nacional de Abastecimento (2020). Acompanhamento da safra brasileira de grãos 2019/20: Décimo-primeiro levantamento. [Accessed Aug. 14 2020]. Available at: https://www.conab.gov.br/info-agro/safras

Cousens, R. (1991). Aspects of the design and interpretation of competition (interference) experiments. Weed Technology, 5, 664-673. https://doi.org/10.1017/S0890037X00027524

Dias, A. C. R., Carvalho, S. J. P., Marcolini, L. W., Melo, M. S. C. and Christoffoleti, P. J. (2010). Competitiveness of alexandergrass or Bengal dayflower with soybean. Planta Daninha, 28, 515-522. https://doi.org/10.1590/S0100-83582010000300008

Fahad, S., Bajwa, A. A., Nazir, U., Anjum, S. A., Farooq, A., Zohaib, A., Sadia, S., Nasim, W., Adkins, S., Saud, S., Ihsan, M. Z., Alharby, H., Wu, C., Wang, D. and Huang, J (2017). Crop production under drought and heat stress: plant responses and management options. Frontiers in Plant Science, 8, 1147. https://doi.org/10.3389/fpls.2017.01147 
Forte, C. T., Basso, F. J. M., Galon, L., Agazzi, L. R., Nonemacher, F. and Concenço, G. (2017). Habilidade competitiva de cultivares de soja transgênica convivendo com plantas daninhas. Revista Brasileira de Ciências Agrárias, 12, 185-193. https://doi.org/10.5039/agraria.v12i2a5444

Franco, J. J., Agostinetto, D., Langaro, A. C., Perboni, L. T. and Vargas, L. (2017). Relative competitiveness of goosegrass biotypes and soybean crops. Revista Caatinga, 30, 271-277. https://doi.org/10.1590/1983-21252017v30n201rc

Galon, L., Tironi, S. P., Rocha, P. R. R., Concenço, G., Silva, A. F., Vargas, L, Silva, A. A., Ferreira, E. A., Minella, E., Soares, E. R. and Ferreira, F. A. (2011). Habilidadecompetitiva de cultivares de cevadaconvivendo comazevém.PlantaDaninha,29,771-781. https://doi.org/10.1590/S0100-83582011000400007

Galon, L., Trevisol, R., Forte, C. T., Tironi, S. P, Reichert Júnior, F. W. and Radunz, A. L. (2017). Competitive ability of bean cultivars with beggarticks. Revista Caatinga, 30, 855-865. https://doi.org/10.1590/1983-21252017v30n405rc

Hoffman, M. L. and Buhler, D. D. (2002). Utilizing Sorghum as a functional model of crop-weed competition. I. Establishing a competitive hierarchy. Weed Science, 50, 466-472. https://doi.org/10.1614/0043-1745(2002)050[0466:USAAFM]2.0.CO;2

Pachauri, R. K., Reisinger, A. and Core Writing Team. (2007). Climate change 2007: synthesis report. Contribution of Working Groups I, II and III to the Fourth Assessment Report of the Intergovernmental Panel on Climate Change. Geneva: IPCC. [Accessed Jun. 20, 2015]. Available at: https://www.ipcc.ch/report/ar4/syr/

Radosevich, S., Holt, J. and Ghersa, C. (2007). Ecology of weeds: relationship to agriculture and natural resource management. Hoboken: John Wiley and Sons.

Ruchel, Q., Agostinetto, D., Zandoná, R., Ulguim, A. R., Avila Neto, R. and Fraga, D. S. (2019). Competitive ability of soybean crop with C and $\mathrm{C}_{4}$ weeds. International Journal of Agriculture and Environmental Research, 5, 669-683.

Silva, A. F., Concenço, G., Aspiazú, I., Ferreira, E. A., Galon, L., Coelho, A. T. C. P., Silva, A. A. and Ferreira, F. A. (2009). Interferência de plantas daninhas em diferentes densidades no crescimento da soja. Planta Daninha, 27,75-84. https://doi.org/10.1590/S0100-83582009000100011

Silva, D. R. O., Agostinetto, D., Vargas, L., Langaro, A. C. and Duarte, T. V. (2014). Habilidade competitiva, alterações no metabolismo secundário e danos celulares de soja competindo com Conyza bonariensis resistente e suscetível a glyphosate. Planta Daninha, 32 , 579-589. https://doi.org/10.1590/S0100-83582014000300014

Silva, D. R. O., Vargas, L., Agostinetto, D. and Santos, F. M. (2017). Photosynthetic performance of glyphosate resistant and glyphosate susceptible fleabane under light intensity. Planta Daninha, 35, e017166275. https://doi.org/10.1590/s0100-83582017350100087

Ulguim, A. R., Agostinetto, D., Vargas, L., Zandoná, R. R., Franco, J. J. and Fraga, D. S. (2016). Competition of wild poinsettia biotypes, with a low-level resistance and susceptible to glyphosate, with soybean. International Journal of Agriculture and Environmental Research, 2 , 1791-1806. https://ainfo.cnptia.embrapa.br/digital/bitstream/item/153377/1/ID48873-2016IJAERv2n6p1791.pdf

Wandscheer, A. C. D., Rizzardi, M. A. and Reichert, M. (2013 b). Competitive ability of corn in coexistence with goosegrass. Planta Daninha, 31, 281-289. https://doi.org/10.1590/S0100-83582013000200005

Wandscheer, A. C. D., Rizzardi, M. A., Reichert, M. and Gaviraghi, F. (2013 a). Competitividade de capim-pé-de-galinha com soja. Ciência Rural, 43, 2125-2131. https://doi.org/10.1590/S0103-84782013001200001

Ziska, L. (2013). Observed changes in soyabean growth and seed yield from Abutilon theophrasti competition as a function of carbon dioxide concentration. Weed Research, 53, 140-145. https://doi.org/10.1111/wre.12005

In the article Effect of high temperature and recovery from stress on crop-weed interaction with DOI: https://doi.org/10.1590/1678-4499.20200138, published in Bragantia vol.79 no.4 Campinas Oct./Dec. 2020:

In the footline where is read Bragantia, Campinas, v. 79, n. 4, p.457-466, 2020 should be read Bragantia, Campinas, v. 79, n. 4, p.582-591, 2020. 